\title{
EFISIENSI TEKNIS ANGGARAN BELANJA SEKTOR KESEHATAN PROPINSI JAWA BARAT
}

\author{
Aristyasani Putri \\ Bank Negara Indonesia \\ sanniiewperv@rocketmail.com
}

\begin{abstract}
.
The purpose of this study was to analyze the efficiency of government spending in the health sektor of West Java province in improving public health as measured by indicators of health status that is Infant Mortality Rate, Mother Mortality Rate, and Life Expectancy Rate in all regencies / cities in West Java Province. DEA method used to achieve these goals. DEA works with measures to identify the units to be evaluated, the input and output of the unit. Furthermore, the calculated value of productivity and identify the unit which does not use inputs efficiently or effectively produces no output. Research indicates that although every region in the province of West Java there is an increase in the health budget annually will produce additional output (facilities and health services) are few and have not been up to meet basic health needs for the community. Budget areas that have not been efficient is because of Rp. 421.8 billion total health budget of the province of West Java is not entirely used for the procurement of facilities and health services. Only 50\% of it is Rp. 213 billion to be used one of them in the provision of health facilities and services.
\end{abstract}

Keyword: Infant Mortality Rate; Mother Mortality Rate; and Life Expectancy Rate; $D E A$.

\begin{abstract}
Abstrak.
Tujuan penelitian ini adalah untuk menganalisis tingkat efisiensi anggaran belanja pemerintah sektor kesehatan di Provinsi Jawa Barat dalam meningkatan kesehatan masyarakat yang diukur berdasarkan indikator derajat kesehatan yaitu $A K B, A K I$, dan AHH di seluruh Kabupaten/Kota di Provinsi Jawa Barat. Metode DEA digunakan untuk mencapai tujuan tersebut. DEA bekerja dengan langkah mengidentifikasi unit-unit yang akan dievaluasi, input serta output unit tersebut. Selanjutnya, dihitung nilai produktivitas dan mengidentifikasi unit mana yang tidak menggunakan input secara efisien atau tidak menghasilkan output secara efektif. Hasil penelitian mengindikasikan bahwa meski setiap daerah di Provinsi Jawa Barat terdapat peningkatan anggaran kesehatan setiap tahunnya akan menghasilkan penambahan output (fasilitas dan layanan kesehatan) yang sedikit dan belum maksimal untuk memenuhi kebutuhan kesehatan dasar bagi masyarakat. Anggaran belanja daerah yang belum efisien ini dikarenakan dari Rp. 421,8 milyar total anggaran kesehatan provinsi Jawa Barat tidak seluruhnya dipergunakan untuk pengadaan fasilitas dan layanan kesehatan. Hanya sebesar 50\% nya yaitu Rp. 213 milyar untuk dipergunakan salah satunya dalam pengadaan fasilitas dan layanan kesehatan.
\end{abstract}

Kata Kunci: Angka Kematian Bayi; Angka Kematian Ibu; Angka Harapan Hidup; DEA.

Diterima: 25 April 2015; Direvisi: 15 Juni 2015; Disetujui: 23 Juni 2015 


\section{PENDAHULUAN}

Pembangunan merupakan proses transformasi jangka panjang yang melibatkan berbagai faktor produksi sebagai input untuk menghasilkan keluaran (output) dan hasil atau (outcome) yaitu berupa kemakmuran dan kesejahteraan. Faktor produksi dalam arti luas meliputi sumber daya alam (natural capital), sumber daya manusia (human capital), dan sumber daya teknologi (technology capital). Ketiga faktor produksi tersebut dikenal dengan modal tradisional pembangunan (BPS, 2012).

Berdasarkan pertimbangan pembangunan berkelanjutan, target pertumbuhan ekonomi dengan meningkatkan pendapatan nasional atau pendapatan perkapita tidak lagi menjadi salah satu bagian utama. Pembangunan bukan hanya dilakukan dalam bidang fisik, seperti pertanian, industri, dan pariwisata, tetapi juga dalam pembangunan SDM (Sumber Daya Manusia memerlukan pengembangan, baik dari segi kuantitas maupun segi kualitas (Priyanto, 2011).

Indonesia terus mencatat pertumbuhan yang signifikan. Berdasarkan data Maret 2013, pertumbuhan baseline perekonomian nasional diperkirakan sebesar 6,2 persen dan naik menjadi 6,5 persen pada tahun 2015. Pendapatan nasional per kapita beranjak naik dari \$2.200 pada tahun 2000 menjadi \$3.563 pada tahun 2012. Indonesia telah membuat rencana pembangunan jangka panjang untuk tahun 2005-2025. Rencana ini dibagi menjadi ke dalam periode lima tahun, masing-masing dengan prioritas pembangunan yang berbeda. Rencana pembangunan jangka menengah untuk tahun 2009-2014 yang salah satunya adalah meningkatkan kualitas sumber daya manusia (Bank Dunia, 2013)

Selanjutnya, UNDP dalam laporannya tentang Pembangunan Sumber Daya Manusia (Human Resouces Development) tahun 2000 menyatakan bahwa "Manusia adalah kekayaan bangsa yang sesungguhnya. Tujuan utama dari pembangunan adalah menciptakan lingkungan yang memungkinkan bagi rakyatnya untuk menikmati umur yang panjang, sehat dan menjalankan kehidupan yang produktif".

Pernyataan tersebut memberikan penekanan bahwa pembangunan berpusat kepada manusia, yang menempatkan manusia sebagai tujuan akhir dari pembangunan dan bukan sebagai alat pembangunan. 
Pencapaian Tujuan Millenium Dunia (Millennium Development Goals) mengkonsentrasikan ada empat tujuan utama Indonesia dalam mencapai derajat kesehatan, kesepakatan yang terjadi dalam Konferensi Tingkat Tinggi (KTT) Milenium di New York ini, Indonesia menjadi salah satu Negara yang menyetujui perjanjian MDGs ini yang kemudian akan diupayakan dapat dicapai pada tahun 2015. Isi perjanjian tersebut antara lain: (1) Menanggulangi kemiskinan dan kelaparan; (2) Mencapai pendidikan dasar untuk semua; (3) Mendorong kesetaraan gender dan pemberdayaan perempuan; (4) Menurunkan angka kematian anak; (5) Meningkatkan kesehatan ibu; (7) Memerangi penyebaran HIV/AIDS, malaria dan penyakit menular lainnya; (8) Kelestarian lingkungan hidup; dan (9) Membangun kemitraan global dalam pembangunan.

Dengan diberlakukannya Otonomi Daerah berdasarkan Undang-Undang No.33 tahun 2004, APBD merupakan instrumen kerja pemerintah dari aspek finansial, dimana anggaran itulah yang akan digunakan pemerintah daerah sebagai dasar untuk melakukan pembangunan daerahnya. Indikator kinerja kegiatan pembangunan adalah ukuran kuantitatif yang menggambarkan tingkat pencapaian suatu kegiatan yang ditetapkan yang dikategorikan dalam masukan (input), keluaran (output), hasil (outcome), manfaat (benefit), dan dampak (impacts) kegiatan pembangunan daerah tersebut (Andriana, 2010).

Berdasarkan Undang-Undang No.36 Tahun 2009, Pasal 171 tentang Pembiayaan Kesehatan, Besar anggaran kesehatan Pemerintah dialokasikan minimal sebesar 5\% (lima persen) dari anggaran pendapatan dan belanja negara di luar gaji, sedangkan untuk daerah Provinsi Kabupaten/Kota dialokasikan minimal $10 \%$ (sepuluh persen) dari anggaran pendapatan dan belanja daerah di luar gaji.

Berdasarkan data yang bersumber dari Direktorat Jenderal Perimbangan Keuangan tahun 2012, alokasi belanja kesehatan Pemerintah Provinsi Jawa Barat pada kurun waktu 4 tahun dari tahun 2009-2012 terus mengalami peningkatan yang signifikan besarannya. Lebih lanjut, meski jumlah anggaran terus meningkat setiap tahunnya, proporsi anggaran belanja kesehatan di Provinsi Jawa Barat masih berada dibawah $10 \%$. Proporsi anggaran belanja sektor kesehatan di Provinsi Jawa Barat pada tahun 2011 yaitu sebesar 2,66\% dari total APBD Provinsi Jawa Barat, proporsi ini menurun dari tahun sebelumnya meski jumlah anggaran terjadi peningkatan. Pada tahun 2012 
proporsi anggaran kesehatan terjadi kenaikan seiring adanya peningkatan anggaran kesehatan menjadi 3,37\%.

Jika dilihat dari proporsi anggaran kesehatan terhadap total APBD maka Provinsi Jawa Barat selalu menempati 5 terbawah posisinya dari seluruh Provinsi yang ada di Indonesia selama periode 4 tahun ini, Provinsi Jawa Barat masih berada pada urutan ke 30 dari 33 Provinsi di Indonesia, dan menjadi posisi paling akhir dari seluruh Provinsi di Pulau Jawa.

Provinsi dengan proporsi alokasi anggaran kesehatan tertinggi tahun 2012 adalah Provinsi Kalimantan Selatan dengan proporsi sebesar 15,63\% dari total APBD. Urutan kedua adalah Provinsi Jawa Timur dengan proporsi alokasi anggaran kesehatannya sebesar $15,04 \%$ dari total APBD. Provinsi dengan proporsi alokasi anggaran kesehatan terendah adalah Papua Barat dengan proporsi sebesar 2,21\% dan Provinsi Gorontalo 3,21\%.

Desentralisasi pada dasarnya adalah penataan mekanisme pengelolaan kebijakan dengan kewenangan yang lebih besar diberikan kepada daerah agar penyelenggaraan pemerintah dan pelaksanaan pembangunan lebih efektif dan efisien (Dina, 2007). Desentralisasi fiskal sendiri diharapkan memberikan dampak terhadap alokasi pengeluaran belanja pemerintah berupa meningkatnya efisiensi pengeluaran pemerintah dan juga tidak kalah pentingnya meningkatnya kinerja dan efisiensi sektor publik (Adam, 2008).

Efisiensi dalam pengeluaran belanja pemerintah daerah didefinisikan sebagai suatu kondisi ketika tidak mungkin lagi realokasi sumber daya yang dilakukan mampu meningkatkan kesejahteraan masyarakat. Dengan kata lain, efisiensi pengeluaran belanja daerah diartikan ketika setiap rupiah yang dibelanjakan oleh pemerintah daerah menghasilkan kesejahteraan masyarakat yang paling optimal (Kurnia, 2006).

Pada prinsipnya desentralisasi bertujuan pada efisiensi sektor publik dalam produksi dan distribusi pelayanan, meningkatkan kualitas pembuatan keputusan dengan menggunakan informasi lokal, meningkatkan akuntabilitas dan meningkatkan kemampuan respon terhadap kebutuhan dan kondisi lokal (Wirahadi dkk., 2012). Dimas (2011) menyatakan bahwa efisiensi dalam belanja kesehatan terjadi ketika dana yang tersedia secara cukup dapat memberikan 
pelayanan kesehatan yang optimal sehingga mampu mencapai derajat kesehatan masyarakat yang baik.

Ditinjau dari aspek derajat kesehatan masyarakat, Rencana Pembangunan Jangka Menengah (RPJM) Provinsi Jawa barat dan ketentuan WHO. Indikator yang dinilai paling peka dan telah disepakati secara nasional sebagai ukuran derajat kesehatan suatu wilayah adalah Angka Harapan Hidup (AHH), Angka Kematian Bayi (AKB), dan Angka Kematian Ibu (AKI).

Pada Tabel 1, kondisi pertumbuhan derajat kesehatan di Provinsi Jawa Barat dapat diketahui bahwa masih terdapat dua indikator derajat kesehatan dari segi mortalitas yaitu AKB dan AKI di Kabupaten/Kota Provinsi Jawa Barat masih memiliki nilai yang positif selama periode penelitian. Indikator AKB dan AKI di Kabupaten/Kota Jawa Barat menunjukan nilai pertumbuhan yang positif atau bertambah. Daerah yang memiliki pertumbuhan AKB negatif hanya 11 daerah, sedangkan daerah yang memiliki pertumbuhan AKI negatif 14 daerah. Berdasarkan ketiga indikator yang merepresentasikan derajat kesehatan di Provinsi Jawa Barat, secara umum derajat kesehatan masyarakat Provinsi Jawa Barat pada tahun 2007-2011 belum menunjukan peningkatan yang sesuai, maka dari itu hal ini masih harus membutuhkan perhatian dan perlu ditingkatkan kembali.

Derajat Kesehatan dapat terus ditingkatkan dengan salah satunya adalah peningkatan pembangunan berbagai fasilitas dan sarana layanan kesehatan publik yang dilakukan baik langsung maupun tidak langsung, dengan keberadaannya yang representatif, murah dan aksesnya mudah untuk dimanfaatkan secara optimal (Profil Kesehatan Jawa Barat, 2012).

Pengembangan dibidang jasa layanan kesehatan merupakan upaya pemerintah dalam rangka meningkatkan kualitas sumber daya manusia dan derajat kesehaatan masyarakat yang optimal. Namun, meski terdapat peningkatan anggaran kesehatan setiap tahunnya, proporsi APBD terhadap belanja kesehatan di Jawa Barat masih rendah yaitu yang masih berada di bawah 15\% sesusai standar WHO dan ketentuan UU Kesehatan. Hal ini terlihat bahwa adanya kesenjangan dan belum tercapainya tujuan pemerintah antara untuk meningkatkan fasilitas dan layanan kesehatan guna meningkatkan pencapaian derajat kesehatan, sementara dari sisi alokasi anggaran sektor publik yaitu anggaran kesehatan belum mencapai hasil yang efisien. 
Berdasarkan UU No. 17 tahun 2003 tentang anggaran berbasis kinerja, pada era otonomi daerah seharusnya meningkatkan efisiensi dan kinerja keuangan daerah dalam mencapai sasaran pembangunan. Oleh karena itu perlu adanya model yang dikembangkan untuk mengukut kinerja serta efisiensi sektor publik guna menjadi salah satu kriteria menilai keberhasilan pemerintah dalam mencapai pembangunan berkelanjutan dan berorientasi sosial masyarakat.

Pelayanan dan transparansi keuangan serta outcome bidang kesehatan merupakan bidang yang banyak menjadi fokus perhatian berbagai instansi baik dalam negeri maupun luar negeri seperti Bank Dunia (World Bank, 2007). Aam Rusydiana (April, 2013) Tingginya pengeluaran kesehatan tidak serta merta menurunkan tingkat kematian dalam jumlah yang signifikan. Oleh karena itu, biaya yang efektif sangat diperlukan, efisiensi sumberdaya kesehatan bukan semata hanya besarannya saja. Evaluasi efisiensi sistem kesehatan melalui layanan dan fasilitas penting untuk meningkatkan derajat kesehatan masyarakat.

Fenomena ini mengindikasikan bahwa tingkat pencapaian derajat kesehatan masyarakat yang terjadi di sebagian besar Kabupaten/Kota Provinsi Jawa Barat pada tahun 2007-2011 masih rendah dan belum sesuai dengan pengelolaan anggaran kesehatan di Kabupaten/Kota di Provinsi Jawa Barat. Fasilitas menjadi salah satu jembatan pengalokasian anggaran kesehatan untuk membantu meningkatkan derajat kesehatan masyarakat apakah fasilitas yang ada sudah efisien dan optimal dalam pengadaannya sesuai dengan anggaran kesehatan yang ada di setiap wilayah.

\section{METODE}

Ruang lingkup penelitian ini adalah Kabupaten/Kota di Provinsi Jawa Barat, dengan kurun waktu pada tahun 2007-2011. Penelitian ini menggunakan 3 variabel penelitian, antara lain Variabel Input yaitu Anggaran Belanja Pemerintah Daerah Kabupaten/Kota Sektor Kesehatan, Variabel Output Intermediate yaitu Fasilitas dan Layanan Kesehatan yang terdiri dari; 1) rasio tempat tidur di rumah sakit per 100.000 penduduk, 2) Rasio Jumlah Tenaga Medis (dokter) di Rumah Sakit per 100.000 penduduk, 3) Jumlah Puskesmas per 100.000 penduduk, dan 4) Rasio Tenaga Bidan di Puskesmas per 100.000 penduduk, dan yang terakhir adalah Variabel Outcome yaitu Indikator Derajat 
Kesehatan seperti Angka Kematian Bayi (AKB), Angka Kematian Ibu Maternal (AKI), dan Angka Harapan Hidup (AHH).

Data dalam penelitian ini merupakan data sekunder makro regional dan mikro regional. Data bersumber dari Rekap Anggaran Pendapatan Belanja Daerah Indonesia dari Dirjen Perimbangan Keuangan, Statistik Keuangan Daerah Provinsi Jawa Barat, Provinsi Jawa Barat dalam Angka.

Jenis data dalam penelitian ini adalah data kuantitatif secara makro regional dan mikro regional. Data kuantitatif berifat makro regional adalah Anggaran Pengeluaran Pemerintah Sektor Kesehatan dari Direktorat Jenderal Perimbangan Keuangan, Rasio Tempat Tidur di Kabupaten/Kota Provinsi Jawa Barat dari Jawa Barat dalam Angka. Data Kuantitatif bersifat mikro regional adalah Jumlah Tenaga Medis (dokter) di Rumah sakit Kabupaten/Kota Jawa Barat, Jumlah puskesmas, dan Jumlah Tenaga kesehatan bidan yang diperoleh dari Laporan Dinas Kesehatan Provinsi Jawa Barat.

Metode yang akan digunakan dalam penelitian ini adalah metode nonparametric Data Envelopment Analaysis (DEA). DEA merupakan suatu teknik programa linier yang digunakan untuk mengevaluasi bagaimana suatu proses pengambilan keputusan dalam suatu unit. Dalam hal ini adalah penelitian tentang mengukur kinerja keuangan Pemerintah berkaitan dengan Anggaran Belanja Pemerintah Sektor Kesehatan dalam pencapaian derajat kesehatan sosial masyarakat di Kabupaten/Kota Provinsi Jawa Barat.

Rusydiana (2013) dalam bukunya Mengukur Tingkat Efisiensi dengan Data Envelopment Analysis, pada dasarnya teknik analisis DEA didesain khusus untuk mengukur efisiensi relatif suatu UKE (Unit Kegiatan Ekonomi) dalam kondisi banyak input maupun output. Kondisi tersebut biasanya sulit disiasati secara sempurna oleh teknik analisis pengukuran efisiensi lainnya. Efisiensi relatif suatu UKE adalah efisiensi suatu UKE dibanding dengan UKE lain dalam sampel yang menggunakan jenis input dan output yang sama. DEA memformulasikan UKE sebagai program linear fraksional untuk mencari solusi, apabila model tersebut ditransformasikan ke dalam program linear dengan nilai bobot dari input dan output.

Efisiensi relatif UKE dalam DEA, juga didefinisikan sebagai rasio dari total ouput tertimbang dibagi total input tertimbang (total weighted output/total weighted input). Inti dari DEA adalah menentukan bobot (weighted) atau timbangan untuk setiap input dan 
output UKE. Setiap UKE diasumsikan bebas menentukan bobot untuk setiap variabelvariabel input maupun output yang ada, asalkan mampu memenuhi dua kondisi yang disyaratkan.

Adapun kedua kondisi yang disyaratkan yaitu: Bobot tidak boleh negatif, dan Bobot harus bersifat universal. Hal ini berarti setiap UKE dalam sampel harus dapat menggunakan seperangkat bobot yang sama untuk mengevaluasi rasionya (total weighted output/total weighted input) dan rasio tersebut tidak lebih dari 1 (total weighted output/total weighted input $\leq 1)$.

DEA berasumsi bahwa setiap UKE akan memiliki bobot yang memaksimumkan rasio efisiensinya (maximize total weighted ouput/total weighted input). Asumsi maksimisasi rasio efisiensi ini menjadikan penelitian DEA ini menggunakan orientasi output dalam menghitung efisiensi teknik. Orientasi lainnya adalah minimisasi input, namun kedua asumsi tersebut akan diperoleh hasil yang sama. Setiap UKE menggunakan kombinasi input yang berbeda untuk menghasilkan kombinasi output yang berbeda, sehingga setiap UKE akan memilih seperangkat bobot yang mencerminkan keragaman tersebut.

Suatu UKE dikatakan efisien secara relatif apabila nilai dualnya sama dengan 1 (nilai efisiensi 100 persen), sebaliknya apabila nilai dualnya kurang dari 1 maka UKE bersangkutan dianggap tidak efisien secara relatif (Rusydiana, 2013).

\section{Teknik Pengukuran Efisiensi}

Pengukuran efisiensi sudah digunakan selama 40 tahun lebih (Coelli, 1996) dan pertama kali dirintis oleh Farrell (1957), dengan mendefinisikan suatu ukuran yang sederhana untuk mengukur efisiensi suatu perusahaan yang dapat memperhitungkan input yang banyak. Efisiensi yang dimaksudkan oleh Farrell terdiri dari efisiensi teknis (technical efficiency) yang merefleksikan kemampuan dari suatu perusahaan untuk memaksimalkan output dengan input tertentu, dan efisiensi alokatif (allocative efficiency) yang merefleksikan kemampuan dari suatu perusahaan yang memanfaatkan input secara optimal dengan tingkat harga yang telah ditetapkan. Kedua ukuran efisiensi ini kemudian dikombinasikan untuk menghasilkan efisiensi ekonomis (total) (Rusydiana, 2013).

Penelitian di Indonesia dengan menggunakan metode DEA atau SFA (Stocatic Frointer Analysis) telah banyak dilakukan, baik di bidang Produksi Perusahaan, Penelitian di 
Universitas tentang Efisiensi Kinerja Keuangan Publik, Efisiensi Perbankan, sampai Efisiensi Kinerja Kesehatan, Pendidikan, dan lain-lain. Aam Rusydiana (2013) menganalisis efisiensi dengan pendekatan DEA diklasifikasikan menjadi dua model orientasi, antara lain:

\section{Pengukuran Berorientasi Input (Input-Oriented Measures).}

Pengukuran berorientasi input menunjukkan untuk penekanan sejumlah input dapat dikurangi secara proporsional tanpa mengubah jumlah output yang dihasilkan. Manajemen mampu menambah atau mengurangi input dengan mudah, dengan kata lain orientasi input tidak berpengaruh terhadap output. Orientasi Input dapat berasumsi Constant Return to Scale (CRS) dan Variable Return to Scale (VRS).

\section{Pengukuran Berorientasi Output (Output-Oriented Measures).}

Pengukuran orientasi output mengukur bilamana sejumlah output dapat ditingkatkan secara proporsional tanpa mengubah jumlah input yg digunakan. Manajemen mempunyai kontrol lebih terhadap output dari pada input. Orientasi Output ini juga dapat berasumsi Constant Return to Scale (CRS) dan Variable Return to Scale (VRS).

Dalam penelitian ini, pengukuran efisiensi yang digunakan menggunakan Orientasi Output (Output-Oriented Measures) untuk mengukur kinerja efisiensi teknis Anggaran Pemerintah Sektor Kesehatan sebagai input yang dibandingkan dengan Fasilitas dan layanan Kesehatan sebagai Output intermediate guna mengetahui efisiensi teknis biaya / alokatif.

Orientasi Input (Input-Oriented Measures) akan digunakan dalam mengukur efisiensi teknis sistem yaitu membandingkan antara Fasilitas dan Layanan yang tersedia sebagai Output intermediate dengan Derajat Kesehatan (AKB, AKI, dan $\mathrm{AHH}$ ) sebagai variabel Output-nya.

\section{Konsep Constant Return to Scale (CRS) dan Variable Return to Scale (VRS).}

Pendekatan DEA lebih menekankan pendekatan yang berorientasi kepada tugas dan lebih memfokuskan kepada tugas yang penting, yaitu mengevaluasi kinerja dari unit pembuat keputusan/UPK (decision making units) (Aam Rusydiana, 2013:21). Dalam pendekatan DEA dikenal dengan dua asumsi berdasarkan hubungan variabel input dengan outputnya, yaitu: 


\section{Constant Return to Scale (CRS)}

Model ini mengasumsikan bahwa rasio antara penambahan input dan output adalah sama (constant return to scale). Artinya, jika ada tambahan input sebesar x kali, maka output akan meningkat sebesar $\mathrm{x}$ kali juga. Asumsi lain yang digunakan dalam model ini adalah bahwa setiap perusahaan atau unit pembuat keputusan (UPK) beroperasi pada skala yang optimal.

Nilai efisinesi selalu kurang atau sama dengan 1. UPK yang nilai efisiensinya kurang dari 1 berarti inefisiensi sedangkan UPK yang nilai efisiensinya sama dengan 1 berarti UPK tersebut efisien.

\section{Variable Return to Scale (VRS)}

Model ini beranggapan bahwa perusahaan atau suatu kinerja keuangan atau fasilitas dan layanan tidak atau belum beroperasi pada skala yang optimal. Asumsi dari model ini adalah bahwa rasio antara penambahan input dan output tidak sama (variable return to scale). Artinya, penambahan input sebesar $x$ kali tidak akan menyebabkan output meningkat sebesar $x$ kali, bisa lebih kecil atau lebih besar dari $x$ kali.

Nilai dari efisiensi tersebut selalu kurang atau sama dengan 1. UPK yang nilai efisiensinya kurang dari 1 berarti inefisiensi sedangkan UPK yang nilainya sama dengan 1 berarti UPK tersebut efisien.

Dalam penelitian ini, pendekatan yang digunakan adalah VRS (variable return to scale). Alasan pemilihan skala efisiensi model VRS ini adalah studi ini ingin mengetahui tingkat efisiensi sebenarnya (tanpa dibatasi oleh kendala apa pun).

\section{Data Envelopment Analysis (DEA)}

Pendekatan nonparametrik dengan program linier (Nonparametric Linear Programming Approach) melakukan pengukuran nonparametrik dengan menggunakan pendekatan yang tidak stokastik dan cenderung "mengkombinasikan" gangguan dan ketidakefisienan. Hal ini dibangun berdasarkan penemuan dan observasi dari populasi dan mengevaluasi efisiensi relatif terhadap unit-unit yang diobservasi. Pendekatan ini dikenal sebagai Data Envelopment Analysis (DEA).

DEA adalah suatu teknik pemrograman matematika yang mengukur tingkat efisiensi dari unit pengambil keputusan (UPK) atau decision-making unit relatif terhadap UPK yang sejenis ketika semua unit-unit ini berada pada atau dibawah "kurva" efisien frontiernya. Keuntungan dari penggunaan DEA adalah bahwa pendekatan ini tidak 
memerlukan spesifikasi yang eksplisit dari bentuk fungsi dan hanya memerlukan sedikit struktur untuk membentuk frontier efisiensinya. Kelemahan yang mungkin muncul adalah "self identifier" dan "near self identifier" (Aam Rusydiana, 2013).

Produktivitas yang diukur bersifat komparatif atau relatif, karena hanya membandingkan antar unit pengukuran dari 1 set data yang sama. DEA adalah model analisis faktor produksi untuk mengukur tingkat efisiensi relatif dari set unit kegiatan ekonomi (UKE) (Yanitra Ega Pamula, 2012). Skor efisiensi dari banyak fator input dan output dirumuskan sebagai berikut:

Efficiency $=\frac{\text { Jumlah Output Tertimbang }}{\text { Jumlah Input Tertimbang }}$

Pengukuran efisiensi yang menyangkut dan input dan output dapat dilaksanakan dengan menggunakan pengukuran efisiensi relatif yang dibobot sebagaimana tertulis sebagai berikut"

Efisiensi dari Unit $j=\frac{u_{1} y_{1 k}+u_{2} y_{2 k}+\cdots}{v_{1} x_{1 k}+v_{2} x_{2 k}+\cdots}, \cdots \cdots \cdots 1$

Namun demikian, pengukuran tersebut tetap memiliki keterbatasan berupa sulitnya menentukan bobot yang seimbang untuk input dan output. Keterbatasan tersebut kemudian dijembatani dengan konsep DEA, efisiensi tidak semata-mata diukur dari rasio output dan input, tetapi juga memasukkan faktor pembobotan dari setiap output dan input yang digunakan. DEA berasumsi bahwa setiap UKE akan memilih bobot yang memaksimumkan rasio efisiensinya (maximize total weighted output/total weighted input).

Karena setiap UKE menggunakan kombinasi input yang berbeda untuk menghasilkan kombinasi output yang berbeda pula, maka setiap UKE akan memilih seperangkat bobot yang mencerminkan keragaman tersebut. Secara umum UKE akan mendapatkan bobot yang tinggi untuk input yang penggunaannya sedikit dan untuk output yang dapat diproduksi dengan banyak. Bobot-bobot tersebut bukan merupakan nilai ekonomis dari input dan outputnya, melainkan sebagai variabel keputusan penentu untuk memaksimumkan efisiensi dari suatu UKE (N. Yartiman, 2012).

Menurut Charnes, Cooper, dan Rhodes (1978) dalam Triyanti Lestari (2013) secara teknis ada dua tahap yang harus dilalui dalam model matematis menggunakan analisis 
DEA. Tahap pertama, model DEA diformulasikan dari persamaan fraksional yang dikenal Fractional Programming (FP) yang menggunakan unit input dan output sebagai variabel keputusan. Kemudian tahap kedua, persamaan (FP) akan di ubah menjadi persamaan linear (LP) ekuivalen melalui metode simpleks untuk menemukan solusi optimal untuk fungsi tujuan.

Efisiensi dalam DEA merupakan solusi dari persamaan berikut:

Maksimumkan Zk $=\frac{\sum_{r}^{S}=1 U_{r k} Y_{r k}^{k}}{\sum_{i}^{m}=1 V_{i k} X_{i k}} \ldots \ldots \ldots . . \ldots 2$

$\frac{\sum_{Y}^{g}=1 U_{r k} Y_{r k}}{\sum_{i}^{m}=1 V_{i k} X_{i k}} \leq 1 \quad k=1,2, \ldots, n \quad \ldots \ldots \ldots .3$

$U_{r k} \geq 0 ; r=1,2, \ldots, s \ldots \ldots \ldots 4$

$V_{i k} \geq 0 ; \mathrm{i}=1,2, \ldots, \mathrm{m} \ldots \ldots \ldots 5$

Persamaan diatas misalkan ada $n$ unit yang akan dibandingkan. Setiap unit menggunakan $m$ input dan $s$ output, dimana $Y_{r k}>0$ dan $X_{i k}>0 . Y_{r k}$ adalah output yang diproduksi oleh $k$ unit, sedangkan $X_{i k}$ adalah input yang digunakan oleh $k$ unit. $U_{r k}$ adalah bobot output $(r=1,2, \ldots, s)$ dan $V_{i k}$ adalah bobot input $(i=1,2, \ldots, m)$.

Salah satu kendala dari pemecahan persamaan (3) adalah persamaan tersebut berbentuk fraksional sehingga sulit dipecahkan dengan pemrograman linear. Namun demikian dengan melakukan linearisasi, persamaan (3) dapat diubah menjadi persamaan linear sehingga pemecahan melalui pemrograman linear dapat dilakukan. Linearisasi persamaan (3) menghasilkan persamaan sebagai berikut :

Maksimumkan Zk $=\sum_{r=1}^{s} U_{r k} Y_{r k} \ldots \ldots \ldots . .4$

Dengan batasan kendala :

$\sum_{r=1}^{s} U_{r k} Y_{r k}-\sum_{i=k}^{m} V_{i k} X_{i k} \leq 0 ; \mathrm{k}=1,2, \ldots, \mathrm{n}, \ldots \ldots \ldots \ldots . .5$

$\sum_{i=k}^{m} V_{i k} X_{i k}=1 \ldots \ldots \ldots \ldots$

$U_{r k} \geq 0 ; r=1,2, \ldots, s \ldots \ldots \ldots \ldots .7$

$V_{i k} \geq 0 ; \mathrm{i}=1,2, \ldots, \mathrm{m} \ldots \ldots \ldots \ldots . . .8$

Menjawab penellitian tentang efisiensi pengeluaran pemerintah ini, persamaan (4) - (8) akan digunakan dalam penelitian untuk mengkalkulasi efisiensi relatif dari belanja daerah sektor kesehatan di Provinsi Jawa Barat. Dimana persamaan diatas dapat dijelaskan sebagai berikut: 
Zk : Kabupaten / Kota yang diamati

$K$ : Kabupaten / Kota yang dinilai dalam analisis yakni $25 \mathrm{Kab} / \mathrm{Kota}$

$Y_{r k}$ : Jumlah output $r$ yang dihasilkan oleh UKE k

$x_{i k}$ : Jumlah input $\mathrm{i}$ yang digunakan UKE $\mathrm{k}$

s : Jumlah output yang dihasilkan (Layanan, Fasilitas Kesehatan \& Derajat Kesehatan)

m : Jumlah input yang digunakan (Anggaran Kesehatan Kab/Kota)

$U_{r k}$ : Bobot tertimbang dari output $r$ yang dihasilkan tiap UKE $\mathrm{k}$

$V_{i k} \quad$ : Bobot tertimbang dari input i yang dihasilkan tiap UKE k

Menurut Yatiman (2012) DEA memiliki beberapa nilai manajerial, antara lain:

DEA menghasilkan efisiensi untuk setiap UKE, relatif terhadap UKE yang lain di dalam sampel. Angka efisiensi ini memungkinkan seseorang analis untuk mengenali UKE yang paling membutuhkan perhatian dan merencanakan tindakan perbaikan bagi UKE yang tidak/kurang efisien.

Jika UKE kurang efisien (efisiensi $<100 \%$ ), DEA menunjukkan sejumlah UKE yang memiliki efisiensi sempurna dan seperangkat angka pengganda yang dapat digunakan oleh manajer untuk menyusun strategi perbaikan. Informasi tersebut memungkinkan seorang analis membuat UKE hipotesis yang menggunakan input yang lebih sedikit dan menghasilkan ouput paling tidak sama atau lebih banyak dibanding UKE yang tidak efisien, sehingga UKE hipotesis tersebut akan memiliki efisiensi yang sempurna jika menggunakan bobot input atau bobot output dari UKE yang tidak efisien.

DEA menyediakan matriks efisiensi silang. Efisiensi silang UKE A terhadap UKE B merupakan rasio dari ouput tertimbang dibagi input tertimbang yang dihitung dengan menggunakan tingkat input dan output UKE $A$ dan bobot input dan output UKE $B$. Analisis efisiensi silang dapat membantu seorang manajer untuk mengenali UKE yang efisien tetapi menggunakan kombinasi input dan menghasilkan kombinasi output yang sangat berbeda dengan UKE yang lain. UKE tersebut sering disebut sebagai Maverick (menyimpang atau unik).

Metode analisis Data Envelopment Analysis (DEA) merupakan prosedur yang didesain secara spesifik untuk mengukur efisiensi relatif suatu unit kegiatan ekonomi (UKE) yang menggunakan banyak input dan banyak output (multi-input multi-output) dangan 
satuan yang berbeda-beda yang sulit disiasati secara sempurna oleh teknik analisis pengukuran efisiensi lainnya (Pertiwi, 2007).

Variabel yang digunakan untuk mengukur serta menganalisis efisiensi adalah dengan menggunakan variabel input dan variabel output. Penelitian ini menggunakan 2 (dua) analisis efisiensi teknis, yaitu Efisiensi Teknis Biaya yaitu membandingkan antara variabel Input dengan variabel Output Intermediate, sedangkan untuk Efisiensi Teknis Sistem yaitu dengan membandingkan antara variabel Output Intermediate dengan variabel Output.

\section{Variabel Input (I)}

Menurut Prijono dan Soesetyo (2008) alokasi belanja kesehatan pemerintah adalah besarnya pengeluaran pemerintah dari total anggaran pendapatan dan belanja yang dialokasikan untuk sektor kesehatan. Variabel belanja pemerintah daerah di sektor kesehatan perkapita pada penelitian ini dalam satuan jutaan rupiah.

\section{Variabel Output Intermediate (OI)}

Variabel Output Intermediate merupakan variabel antara yang dibandingkan dengan variabel Input untuk mengukur Efisiensi Teknis Biaya dan dibandingkan dengan variabel Output untuk mengukur Efisiensi Teknis Sistem, variabel yang digunakan antara lain:

Rasio Jumlah Tenaga Medis (Dokter) di Rumah Sakit per 100.000 Penduduk.

Berdasarkan Djafarov dan Gunnarson, 2008, merupakan jumlah per 100.000 penduduk yang bertugas di rumah sakit pemerintah, puskesmas, puskesmas pembantu atau fasilitas kesehatan publik milik pemerintah lainnya di suatu wilayah dalam kurun waktu tertentu. Penghitungan indikator ini diperoleh melalui formula sebagai berikut:

\section{Jumlah dokter di suatu wilayah tertentu selama satu tahun $\times 100.000$ $\overline{\text { Tumlah penduduk di suatu wilayah dalam }} \times 100.000 \quad \ldots \ldots \ldots . . .9$ kurun waktu yang sama}

Rasio Jumlah Tempat Tidur yang Tersedia di Rumah Sakit per 100.000 penduduk. Variabel ini merupakan indikator dari fasilitas layanan kesehatan yang disediakan pemerintah yang dihitung dari jumlah tempat tidur tersedia di rumah sakit milik pemerintah dalam satu tahun tertentu (Djafarov dan Gunnarsson, 2008). Penggunaan 
indikator ini menggambarkan daya tampung rumah sakit milik pemerintah. Penghitungan indikator ini diperoleh melalui formula sebagai berikut:

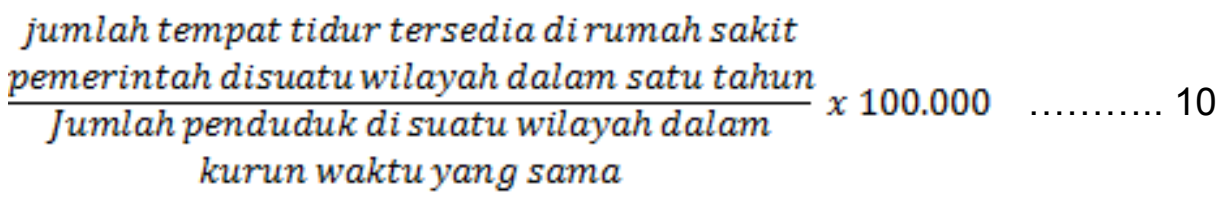

Rasio Jumlah Puskesmas per 100.000 Penduduk.

Jumlah Puskesmas per 100.000 penduduk merupakan Salah satu indicator yang digunakan untuk mengetahui keterjangkauan penduduk terhadap puskesmas di suatu wilayah (Profil Kesehatan Provinsi Jawa Barat). Penghitungan indikator ini diperoleh melalui formula sebagai berikut:

Jumlah puskesmas di suatu wilayah tertentu

dalam satu tahun
$\begin{gathered}\text { Jumlah penduduk disuatu wilayah } \\ \text { dalam kurun waktu yang sama }\end{gathered} 100.000 \quad \ldots \ldots \ldots \ldots . . .11$

Rasio Jumlah Tenaga Bidan per 100.000 penduduk Jumlah bidan per 100.000 penduduk merupakan jumlah bidan yang bertugas di rumah sakit pemerintah, puskesmas, puskesmas pembantu atau fasilitas kesehatan publik milik pemerintah lainnya di suatu wilayah dalam kurun waktu tertentu. Untuk mendapatkan angka indikator ini dapat diperoleh dengan formula sebagai berikut:

Jumlah bidan di puskesmas disuatu wilayah

dalam kurun waktu satu tahun
$\begin{gathered}\text { Jumlah penduduk disuatu wilayah } \\ \text { dalam kurun waktu yang sama }\end{gathered} 100.000 \quad \ldots \ldots \ldots \ldots . . . . .12$

\section{Variabel Outcome (0)}

Angka Kematian Bayi per 1000 Jumlah Kelahiran (AKB).

Definisi kematian bayi menurut Kementerian Kesehatan adalah jumlah kematian yang terjadi pada bayi sebelum mencapai usia satu tahun, sedangkan kelahiran hidup yaitu janin pada waktu lahir memperlihatkan tanpa kehidupan, formula pengukuran indikatornya adalah:

Jumlah bayi yang meninggal disuatu wilayah tertentu selama satu tahun 13 $\overline{J u m l a h \text { kelahiran hidup di wilayah dan kurun }} \times 1.000$ waktu yang sama 
Indikator AKB merupakan indikator derajat kesehatan yang memiliki karakteristik negatif, artinya semakin rendah nilai dari AKB maka menggambarkan semakin baik kondisi derajat kesehatan. Hal ini bertentangan dengan salah satu syarat penghitungan efisiensi dengan menggunakan analisis DEA yaitu bobot harus berkarakteristik positif sehingga indikator AKB dalam analisis ini diproksi dengan Angka Bayi Hidup ( $A B H)$ yang di dapat dengan formula:

\section{Jumlah bayi yang hidup disuatu wilayah} $\frac{\text { tertentu selama satu tahun }}{\text { Jumlah kelahiran hidup diwilayah dan kurun }} \times 1.000$ waktu yang sama 14

Angka bayi hidup merupakan angka yang berkebalikan dengan angka kematian bayi, sehingga jumlah bayi hidup yang meningkat mencerminkan jumlah kematian bayi yang berkurang.

Angka Kematian Ibu Maternal per 100.000 Kelahiran Hidup.

Definisi angka kematian ibu maternal menurut Badan Pusat Statistik adalah kematian perempuan pada saat hamil atau kematian dalam kurun waktu 42 hari sejak terminasi kehamilan tanpa memandang lamanya kehamilan atau tempat persalinan, yakni kematian yang disebabkan karena kehamilannya atau pengelolaannya, tetapi bukan karena sebab-sebab lain seperti kecelakaan, terjatuh dan lain-lain. Adapun untuk angka kematian ibu maternal per 100.000 kelahiran hidup dapat di hitung dengan formula:

Jumlah kematian ibumaternal disuatu

wilayah tertentu selama satu tahun
$\quad$ Jumlah kelahiran hidup di wilayah
$\quad$ dan kurun waktu yang sama

Sama halnya dengan indikator AKB, indikator AKI memiliki karakteristik yang negatif, sehingga dalam analisis ini indikator AKI diproksi dengan menggunakan indikator Angka Ibu Melahirkan Selamat (AIMS) yang didapat dengan formula:

Jumlah ibu melahirkan dengan selamat

diwilayah tertentu selama satu tahun
$\quad$ Jumlah kelahiran hidup di wilayah
darun waktu tertentu

AIMS merupakan angka yang berkebalikan dengan AKI, sehingga jumlah AIMS yang meningkat akan mencerminkan jumlah AKI yang menurun. 
Angka Harapan Hidup (AHH).

Definisi Angka Harapan Hidup menurut Badan Pusat Statistik adalah ratarata tahun hidup yang masih akan dijalani oleh seseorang yang telah berhasil mencapai umur tertentu, pada tahun tertentu, dalam situasi mortalitas yang berlaku di lingkungan masyarakatnya. Sedangkan Angka Harapan Hidup saat lahir adalah rata-rata lamannya hidup (dalam tahun) sejak lahir yang akan dicapai oleh penduduk dalam suatu wilayah dan waktu tertentu yang dihitung berdasarkan angka kematian menurut kelompok umur. Dalam penelitian ini yang digunakan adalah Angka Harapan hidup saat lahir.

\section{HASIL DAN PEMBAHASAN}

Nilai efisiensi dari belanja pemerintah sektor kesehatan dalam penelitian ini diperoleh dengan metode Data Envelopment Analysis (DEA). Penelitian ini menggunakan asumsi Variable Return to Scale (VRS) yang berorientasi input (Input Oriented) untuk menganalisis efisiensi teknis biaya, sedangkan berorientasi output (Output Oriented) untuk menganalisis efisiensi teknis sistem dengan bantuan Software Deawin.exe.

DEA akan menghasilkan nilai efisiensi relatif antar unit kegiatan ekonomi (UKE) yang diteliti. Unit kegiatan ekonomi (UKE) penelitian ini terdiri atas 25 Kabupaten/Kota di Jawa Barat pada Tahun 2007-2011. Kab/kota yang memiliki nilai efisiensi terbaik yakni $100 \%$ dijadikan sebagai acuan (bencmark) bagi Kab/Kota lainnya, sedangkan nilai $0-100 \%$ merupakan nilai inefisien.

DEA selain dapat menghasilkan nilai efisiensi juga dapat menghasilkan potential improvement atau tingkat perbaikan yang diperlukan. Untuk meningkatkan tingkat efisiensi yang ditunjukkan dengan angka 100\% maka dapat diketahui input mana saja yang belum efisien penggunaannya dan output mana saja yang harus ditingkatkan. Yang dimaksud dengan efisien adalah menghasilkan suatu nilai output yang maksimum dengan sejumlah input tertentu, atau dengan input minimum dapat menghasilkan output tertentu.

\section{Efisiensi Teknis Biaya Anggaran Belanja Sektor Kesehatan}

Nilai efisiensi teknis biaya Kabupaten/Kota Provinsi Jawa Barat diperoleh dengan menggunakan varibel input berupa anggaran belanja pemerintah sektor kesehatan yang dikeluarkan masing-masing pemerintah daerah kabupaten/kota. Sedangkan variabel output yang digunakan adalah variable output intermediate yaitu fasilitas dan 
layanan kesehatan yang terdiri dari rasio tempat tidur di rumah sakit, rasio dokter di rumah sakit, rasio puskesmas, dan rasio bidan di puskesmas.

Asumsi yang digunakan adalah Variable Return to Scale (VRS) dengan orientasi input (Input Oriented). Efisiensi teknis biaya digunakan untuk melihat sejauh mana tingkat efisiensi penggunaan input berupa belanja kesehatan yang dikeluarkan masingmasing pemerintah daerah di Provinsi Jawa Barat untuk menghasilkan fasilitas dan layanan kesehatan dasar dalam rangka mencapai derajat kesehatan masyarakat yang baik.

Terdapat dua Kota di Provinsi Jawa Barat yang selalu mencapai nilai efisien 100\% secara teknis biaya yaitu Kota Cirebon dan Kota Sukabumi. Selanjutnya kedua daerah tersebut dapat dijadikan bencmark (wilayah acuan) bagi Kab/Kota lainnya.

Kota Cirebon dan Kota Sukabumi memiliki nilai proporsi anggaran kesehatan hanya sebesar $2,3 \%$ dan $0,98 \%$ dari total APBD daerahnya, kemudian rata-rata belanja kesehatan selama 5 tahun sebesar 88,1 milyar dan 74,6 juta. Namun demikian, kedua wilayah ini dapat mencapai nilai efisien secara teknis biaya meski proporsi belanja kesehatan masih jauh dari ketentuan Undang-Undang (10\% dari total APBD). Dengan kata lain, wilayah ini sudah mampu menggunakan sejumlah input anggaran belanjanya kesehatan seminimal mungkin dalam pengadaan fasilitas dan layanan yang maksimum, baik anggaran tersebut ditambah atau dikurangi dalam setiap kebijakan yang diambil setiap tahunnya.

Sedangkan dalam periode 5 tahun ini, terdapat delapan Kabupaten/Kota yang mencapai nilai $100 \%$ secara teknis biaya. Kota Tasikmalaya dan Kota Banjar adalah yang paling berfluktuatif nilai efisiennya, yaitu dengan rata-rata efisiensi di atas $50 \%$ yang masing-masing sebesar $76,4 \%$ dan $61,24 \%$ per lima tahun. Kota Tasikmalaya memiliki nilai efisiensi $100 \%$ berturut-turut selama 3 tahun 2008-2010, namun pada tahun 2011 turun menjadi 71,4\% dikarenakan proporsi anggaran belanja kesehatannya menurun dari tahun 2010 sebesar 10,5\% menjadi 7,4\% dari total APBD Provinsi Jawa Barat.

Namun untuk Kota Banjar peningkatan nilai efisiensi dari tahun 2010 hanya 14,3\% menjadi 100\% pada tahun 2011 membuktikan bahwa Kota Banjar mampu menggunakan anggaran belanja daerahnya dengan efisien. Meskipun proporsi anggaran belanja daerahnya hanya $0,7 \%$ dari total APBD Provinsi Jawa Barat. 
Sedangkan $6 \mathrm{Kab} /$ Kota di Provinsi Jawa Barat yang sudah mencapai nilai efisien teknis biaya selama 5 tahun meski rata-rata efisiennya dibawah $50 \%$ antara lain Kabupaten Cirebon, Kabupaten Indramayu, Kabupaten Kuningan, Kabupaten Sukabumi, Kabupaten Tasikmalaya, dan Kota Cimahi.

Pencapaian efisiensi di seluruh wilayah Kabupaten/Kota Provinsi Jawa Barat diketahui 2 kota (8\%) yang mencapai nilai efisien 100\%, sedangkan 84\% wilayah Kabupaten/Kota Provinsi Jawa Barat masih berada di bawah nilai efisien 50\% secara teknis sistem. Bagi daerah yang pencapaian efisiennya belum mencapai $100 \%$ bahkan kurang dari 50\%, fenomena ini menjelaskan bahwa dalam pengalokasian anggaran kesehatannya belum efisien meski tidak ada penambahan layanan atau fasilitas kesehatan.

\section{Efisiensi Teknik Sistem Kesehatan}

Nilai efisiensi teknis sistem kesehatan Kabupapten/Kota Provinsi Jawa Barat bersifat relatif dengan menggunakan input fasilitas dan layanan dasar kesehatan masyarakat baik di rumah sakit dan di puskesmas yaitu yang terdiri dari rasio tempat tidur di rumah sakit, rasio dokter di rumah sakit, rasio puskesmas, dan rasio bidan dipuskesmas. Sedangkan untuk dibandingkan dengan variabel output derajat kesehatan yang digunakan antara lain Angka Kematian Bayi (AKB) yang diproksi oleh Angka Bayi Hidup (ABH) per 1000 penduduk, Angka Kematian Ibu (AKI) yang diproksi oleh Angka Ibu Melahirkan Selamat (AIMS) per 100.000 penduduk, dan Angka Harapan Hidup $(\mathrm{AHH})$.

Asumsi yang digunakan adalah Variable Return to Scale (VRS) dengan orientasi output (Output Oriented). Nilai efisiensi teknis sistem ini menggambarkan bahwa besarnya input fasilitas dan layanan kesehatan yang diupayakan pemerintah daerah mampu menghasilkan jumlah derajat kesehatan masyarakat dengan besaran yang berbeda-beda (tidak konstan).

Nilai efisiensi teknis sistem di Provinsi Jawa Barat memiliki pencapaian yang lebih baik dibanding efisiensi teknis biaya. Diketahui bahwa terdapat 5 Kabupaten/Kota (20\%) wilayah yang mencapai nilai efisien selama 5 periode tahun penelitian, yaitu Kabupaten Bandung, Kabupaten Tasikmalaya, Kota Bandung, Kota Bekasi, dan Kota Depok.

Sedangkan ada 14 Kabupaten/Kota (56\%) wilayah yang nilai efisien teknis sistemnya berfluktuatif berkisar antara $90-100 \%$ selama 5 periode tahun 
penelitian. Kemudian sekitar $24 \%$ sisanya ada 6 Kabupaten/Kota yang belum dapat mencapai angka 100\% atau efisien secara sistem dalam 5 periode penelitian.

Kabupaten/Kota Provinsi Jawa Barat yang sudah mencapai nilai efisien secara teknis sistem ini membuktikan bahwa dengan pelayanan dan fasilitas yang ada dapat meningkatkan jumlah bayi hidup, jumlah ibu melahirkan selamat, dan angka harapan hidup yang lebih baik. Lebih lanjut, efisien secara teknis sistem dalam sektor kesehatan dapat juga berarti setiap penambahan fasilitas kesehatan dan layanan kesehatan yang dilakukan daerah-daerah yang efisien akan menghasilkan tambahan sejumlah output berupa derajat kesehatan yang sama.

Namun demikian, bagi daerah yang nilai efisiennya masih $<100 \%$ (inefisien) masih belum dapat mencapai efisien secara teknis sistem. Semakin kecil pencapaian skor efisien maka semakin tidak efisien daerah tersebut dalam penggunaan fasilitas layanan kesehatan. Oleh karena itu dapat dikaitkan dengan hukum penurunan hasil (The Law of Deminishing Return) jika penambahan fasilitas dan layanan kesehatan tidak diiringi dengan perbaikan sistem pelayanan, pemerataan keterjangkauan fasilitas per 100.000 penduduk di setiap wilayah, maka penambahan output yang diharapkan untuk meningkatkan derajat kesehatan tidak akan optimal.

\section{Meningkatkan Nilai Efisiensi Teknis Biaya Melalui Bencmarking Area}

Pada periode penelitian Tahun 2007-2011 Kabupaten/Kota Provinsi Jawa Barat daerah yang menjadi bencmark pada efisiensi teknis biaya antara lain Kota Cirebon, Kota Tasikmalaya, dan Kota Sukabumi, hal ini dikarenakan Kota Tasikmalaya bernilai efisien dalam 3 periode penelitian 2008-2010. Sedangkan Kota Cirebon dan Kota Sukabumi selalu bernilai efisien $100 \%$ pada 5 tahun periode penelitian.

Kemudian akan diambil masing-masing satu wilayah per tahun penelitian yang akan di tingkatkan efisiensinya menggunakan wilayah bencmark tersebut. Berdasarkan Tabel.4.5 diatas maka diketahui bahwa setiap daerah yang belum mencapai nilai efisien telah memiliki masing-masing wilayah yang dapat dijadikan bencmark nya untuk meningkatkan efisiensi input serta outputnya. Berdasarkan Tabel 1, dapat dijelaskan sebagai berikut: 
Tahun 2007

Kota Bandung memiliki nilai efisien 1,23\%, maka untuk meningkatkan efisiensinya menjadi $100 \%$ wilayah tersebut dapat mengurangi inputnya sebesar 98,77\%. Jika Kota Bandung ingin mencapai efisiensi secara teknis biaya, langkah kebijakannya adalah menekan belanja kesehatan untuk layanan dan fasilitas sebesar 98,77\% dari jumlah actual Rp. 111.628 .940 .830 menjadi sekitar Rp. 1.376.734.991.

Mengacu pada wilayah Bencmark-nya maka Kota Bandung dapat melakukan perbaikan anggaran kesehatan agar efisien sebagai berikut:

Anggaran Kota Bandung Rp. 111.628.940.830, Bencmark Area:

Kota Cirebon $\quad=0,024$ (anggaran Kota Cirebon)

$$
\begin{aligned}
& =0,024(57.454 .617 .633) \\
& =1.369 .325 .544
\end{aligned}
$$

Kota Sukabumi $\quad=0,976$ (anggaran Kota Sukabumi)

$$
=0,976(7.590 .349)
$$$$
=7.409 .466
$$

Maka untuk mencapai anggaran yang efisien Kota Bandung dapat menekan anggaran belanja sektor kesehatan sekitar Rp. 1.376.735.010 sesuai dengan kedua wilayah Bencmark-nya.

Tabel 1.

Acuan Wilayah untuk Mencapai Nilai Efisiensi Teknis Biaya Kabupaten/Kota Provinsi Jawa Barat

\begin{tabular}{|c|l|c|l|c|}
\hline TAHUN & Kabupaten/Kota & $\begin{array}{c}\text { Efisiensi } \\
(\boldsymbol{\%})\end{array}$ & $\begin{array}{c}\text { Benmark Area } \\
\left(\begin{array}{c}\text { Efficient Reference } \\
\text { Set })\end{array}\right.\end{array}$ & $\begin{array}{c}\text { Shadow Price } \\
\text { (Angka Pengganda) }\end{array}$ \\
\hline $\mathbf{2 0 0 7}$ & Kota Bandung & $1,23 \%$ & Kota Cirebon & 0,024 \\
\hline & & & Kota Sukabumi & 0,976 \\
\hline $\mathbf{2 0 0 8}$ & Kabupaten Karawang & $0,07 \%$ & Kota Sukabumi & 0,397 \\
\hline & & & Kota Tasikmalaya & 0,603 \\
\hline $\mathbf{2 0 0 9}$ & Kabupaten Majalengka & $28,72 \%$ & Kota Cirebon & 0,293 \\
\hline & & & Kota Tasikmalaya & 0,707 \\
\hline $\mathbf{2 0 1 0}$ & Kabupaten Ciamis & $0,02 \%$ & Kota Cirebon & 0,150 \\
\hline & & & Kota Sukabumi & 0,100 \\
\hline & & & Kota Tasikmalaya & 0,750 \\
\hline $\mathbf{2 0 1 1}$ & Kota Bekasi & $0,05 \%$ & Kota Sukabumi & 1,000 \\
\hline
\end{tabular}

Sumber: Hasil Olahan Data 


\section{SIMPULAN}

Belanja Kesehatan merupakan salah satu belanja pembangunan, yang merupakan pengeluaran yang bertujuan untuk pembiayaan proses perubahan dan bersifat menambah modal masyarakat baik dalam bentuk pembangunan fisik maupun non fisik. Kriteria belanja sektor kesehatan secara umum ke dalam lima aspek, yaitu; (1) pelayanan kesehatan dan jasa-jasa sanitasi lingkungan; (2) rumah sakit, institusi kesejahteraan sosial; (3) pendidikan, pelatihan, penelitian medis murni; (4) pekerjaan medis sosial, kerja sosial; (5) praktisi medis dan penyedia pelayanan kesehatan tradisional. Sektor-sektor tersebut yang kemudian akan mendapat alokasi belanja kesehatan dari pemerintah.

Peningkatan Angka Harapan Hidup $(\mathrm{AHH})$ disetiap wilayah Kabupaten/Kota Provinsi Jawa Barat belum maksimal. Sementara AKB dan AKI di Kabupaten/kota Provinsi Jawa Barat diketahui positif pertumbuhannya, kematian bayi di seluruh Kabupaten/Kota Provinsi Jawa Barat mencapai 5.142 bayi dari 915.280 kelahiran hidup sedangkan terdapat 850 orang dari (93.0 / 100.000 kelahiran hidup).

\section{PUSTAKA ACUAN}

Andriana, Noviana. 2011. Analisis Anggaran Pendapatan Belanja Daerah Terhadap Realisasi Tata Kelola Anggaran Pembangunan di Sektor Pendidikan Pemerintah Kabupaten Jombang. Tesis, Brawijaya.

Atmawikarta, Arum. 2005. Investasi Kesehatan untuk Pembangunan Ekonomi”, BAPPENAS.

Badan Pusat Statistik. Jawa Barat Dalam Angka. edisi : 2008-2012. Provinsi Jawa Barat.

Badan Pusat Statistik. Kematian Bayi dan Angka Harapan Hidup Penduduk Indonesia (Hasil SP2010). Jakarta, 2012.

Badan Pusat Statistik. Menuju Era Baru Kependudukan Provinsi Jawa Barat : Analisis Profil Kependudukan Provinisi Jawa Barat (Hasil SP2010). Provinsi Jawa Barat, 2012.

Chalid, Pheni. 2005. Keuangan Daerah, Investasi, dan Desentralisasi. Tantangan dan Hambatan. Cetakan Pertama, Kemitraan, Jakarta.

Dinas Kesehatan Provinsi Jawa Barat, "Profil Kesehatan Provinisi Jawa Barat", berbagai edisi: 2007-2012, Jawa Barat. 
Jafarov, E dan Victoria Gunnarsson. 2008. Efficiency of Government Sosial Spending in Croatia, Washington USA.

Kurnia, Akhmad Syakir. 2006. Model Pengukuran Kinerja dan Efisiensi Sektor Publik Metode Free Disposable Hull (FDH), Jurnal Ekonomi Pembangunan Universitas Dipenogoro Vol.11 No.2 Hal: 1-20, Semarang.

Lena, Dina Pertiwi. 2007. Efisiesi Pengeluaran Pemerintah Daerah di Provinsi Jawa Tengah. Jurnal Ekonomi Pembangunan Vol.12 No.2 Hal: 123 - 139, Yogyakarta.

Maharani, Devi Lintang F. 2001. Analisis Efisiensi Teknis Anggaran Belanja Kesehatan Pemerintah Kabupaten/Kota Provinsi Jawa Tengah. Skripsi Universitas Dipenogoro, Semarang.

Mangkoesoebroto, Guritno. 1993. Ekonomi Publik. edisi 3, BPFE, Yogyakarta.

Muluk, Khairul M.R. 2005. Desentralisasi \& Pemerintah Daerah. Edisi Pertama, Bayumedia, Malang, Jawa Timur.

Pamula, Yanitra Ega. 2012. Efisiensi Sektor Publik Pendekatan Data Envelopment Analysis di Indonesia 2001-2008, Universitas Dipenogoro, Semarang, 36-40.

Rusyidiana, Aam Slamet. 2013. Mengukur Tingkat Efisiensi dengan Metode Data Envelopment Analysis (DEA). Cetakan Pertama Februari 2013, Tim SMART Consulting, Katulampa Bogor.

Sapha, Diana A. H. 2013. Analisis Pengaruh Belanja Kesehatan oleh Pemerintah Terhadap Derajat Kesehatan Masyrakat di Provinsi Aceh. Jurnal Hal. 39 dan 45, Fakultas Ekonomi, Universitas Syiah Kuala, Darussalam, Banda Aceh.

Santerre, Rexford E dan Stephen, P Neun. 2010. Health Economics - Theory, Insights, and Industry Studies. Edisi kelima, South-Western Cengage Learning, USA: 4-5.

Sebayang, Asnita Frida. 2005. Kinerja Kebijakan Fiskal Daerah di Indonesia Pasca Crisis. Jurnal Fakultas Ekonomi Universitas Islam Bandung, Jurnal Ekonomi Pembangunan Vol. 10 No. 3: 204-208.

Susilowati, Indah. 2004. Modul Mengukur Efisiensi dengan Metode Data Envelopment Analysis (DEA) DEAWIN.exe. Fakultas Ekonomi, Universitas Dipenogoro, Semarang:1-3.

Shafitranata. 2012. Tingkat Efisiensi Bank Umum Syariah (BUS) Menggunakan Metode Data Envelopment Analysis (DEA)", Jurnal Hal. 3-9, Jakarta.

Todaro, Michael P dan Stephen, C. Smith. 2012. Economic Development. Edisi sebelas, Pearson Education, Boston: 7 dan 356

Undang-Undang Republik Indonesia No.36 Tahun 2009 tentang Kesehatan. 
Yatiman N. Arif Pujiyono. 2013. Analisis Efisiensi Teknis Anggaran Belanja Sektor Kesehatan Pemerintah Daerah Kabupaten/Kota di Provinsi Daerah Istimewa Yogyakarta Tahun 2008-2010. Diponegoro Journal Of Economics Vol.2 No.1 Hal. 1-13, Semarang. 